\title{
PHOTOLUMINESCENCE CHARACTERISATION OF GaAs/AIGaAs STRUCTURES DESIGNED FOR MICROWAVE AND TERAHERTZ DETECTORS
}

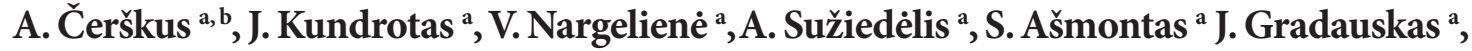 \\ A. Johannessen ${ }^{c}$, and E. Johannessen ${ }^{c}$ \\ a Semiconductor Physics Institute, Center for Physical Sciences and Technology, A. Goštauto 11, LT-01108 \\ Vilnius, Lithuania \\ ${ }^{\mathbf{b}}$ Vilnius Pedagogical University, Studentų 39, LT-08106 Vilnius, Lithuania \\ E-mail: a_cerskus@yahoo.com \\ ${ }^{\mathfrak{c}}$ Vestfold University College, Raveien 197, 3184 Borre, Norway
}

Received 28 October 2011; accepted 1 December 2011

\begin{abstract}
The photoluminescence (PL) spectra of GaAs/AlGaAs structures designed for microwave and terahertz detectors were investigated. Detailed experimental results of PL were obtained both before and after etching of the heavily doped layers. Possible mechanisms of carrier recombination are discussed and certain emphasis is put on the up to 20 times enhancement of the PL intensity observed in these detector structures.
\end{abstract}

Keywords: GaAs, AlGaAs, homojunction, photoluminescence, exciton, PL enhancement

PACS: 78.55.-m, 71.55.Eq, 71.35.-y

\section{Introduction}

The current research in the field of communication technology aims to increase the operational bandwidth of emitters and detectors. The greatest achievements have been reported in the visible, near-infrared and microwave (MW) bands. However, the performance of already existing devices in the high frequency MW region as well as in the terahertz $(\mathrm{THz})$ range is still considered as being modest. Therefore, a new generation of emitters $[1,2]$ and detectors [3] based on $n^{+} / n, n^{+} / i$ or $p^{+} / i$ homojunctions, has been proposed for operation in $\mathrm{MW}$ and $\mathrm{THz}$ ranges. The characteristics of these devices have not been fully investigated so far.

We have designed a novel device model based on GaAs and AlGaAs structures for the implementation in the MW and $\mathrm{THz}$ range for broad band detection [4]. In this paper we present a photoluminescence characterisation of these structures. We discuss possible mechanisms of carrier recom- bination and put an emphasis on the enhancement of photoluminescence (PL) that is observed in these structures.

\section{Samples and measurement technique}

The structures were grown by molecular beam epitaxy (MBE) on a semi-insulating GaAs substrate. The active region consisted of two homojunctions: Si doped $n^{+} / n \mathrm{Al}_{x} \mathrm{Ga}_{1-x}$ As and $n / n^{+}$GaAs. The layered composition of the $\mathrm{GaAs} / \mathrm{Al}_{x} \mathrm{Ga}_{1-x}$ As structure is shown in Fig. 1. Samples \#1, \#2, \#3, \#4 were grown with a different aluminium mole fraction in the active region containing, respectively, $x=0.3,0.25$, $0.2,0.1$.

An argon-ion laser operating in a continuous wave mode was used for the sample excitation with a photon energy ranging from 2.4 to $2.7 \mathrm{eV}$. The PL signal was dispersed by a monochromator and detected by a thermoelectrically cooled GaAs photomultiplier operating in the photon counting regime. The PL spectra of the structures were 


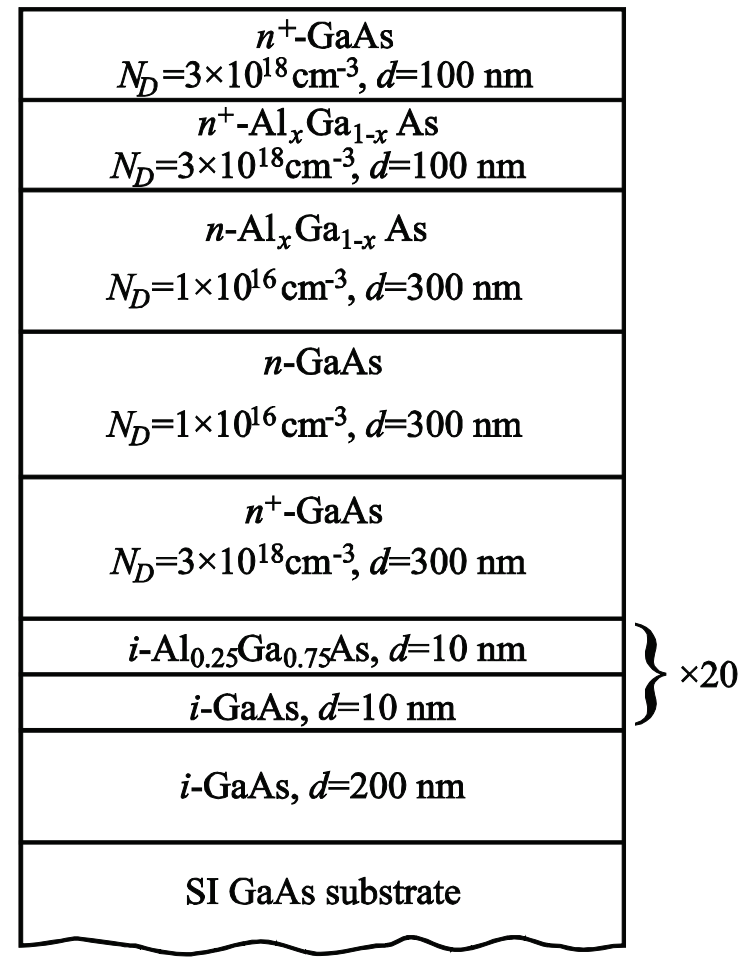

Fig. 1. The structure of the $\mathrm{GaAs} / \mathrm{Al}_{x} \mathrm{Ga}_{1-x} \mathrm{As}$ sample.

measured using various excitation intensities in the range from $2 \mathrm{~mW} / \mathrm{cm}^{2}$ to $6.8 \mathrm{~W} / \mathrm{cm}^{2}$. The laser excitation intensity was changed by using neutral glass filters or by varying the output power of the laser by controller. A closed cycle helium optical cryostat enabled the sample temperatures to be changed from an ambient $300 \mathrm{~K}$ down to $3.6 \mathrm{~K}$.

The chemical etching of the top layers was performed using a $\mathrm{H}_{3} \mathrm{PO}_{4}: \mathrm{H}_{2} \mathrm{O}_{2}: \mathrm{H}_{2} \mathrm{O}=1: 1: 50$ solution. The etching was controlled with a profilometer by leaving some part of the sample unetched.

\section{Experimental results}

The PL spectra of GaAs/Al $\mathrm{Ga}_{1-x}$ As structures with a different Al mole fraction $x$ at a temperature of $3.6 \mathrm{~K}$ and a laser excitation intensity of $I=1.36 \mathrm{~W} / \mathrm{cm}^{2}$ are presented in Fig. 2. One can resolve two parts of the spectra indicated by segments. The first one, below $1.57 \mathrm{eV}$, is attributed to the GaAs layers. An emission below the forbidden energy gap, $E_{\mathrm{g}}(\mathrm{GaAs})=1.519 \mathrm{eV}$, is related to the lightly doped $\mathrm{GaAs}$ layer. The lower energy transitions at $1.49 \mathrm{eV}$, labelled $A$, are the recombination of free electron with the residual acceptor. The transition at $1.515 \mathrm{eV}$ is a well-known free exciton line [5] (marked as $X$ in Fig. 2). The broad band from 1.5 to $1.57 \mathrm{eV}$ is attributed to the emission from the heavily doped GaAs layer $\left(n^{+}-\mathrm{GaAs}\right)$. This broad band nearly disappeared from the spectra when the top $n^{+}$-GaAs layer was removed by etching. The radiation of multiple quantum wells (QWs) in the buffer layer at $1.547 \mathrm{eV}$ is not clearly distinguished in Fig. 2. Clear excitonic lines radiating from QWs were only observed after the etching of all the top layers.

The second part of the PL spectra is associated with the $\mathrm{Al}_{x} \mathrm{Ga}_{1-x}$ As layers. It can be shown that the PL intensity from $\mathrm{Al}_{x} \mathrm{Ga}_{1-x}$ As decreases with the decrease of the $\mathrm{Al}$ mole fraction. This part of the PL spectrum can be interpreted as the superposition of

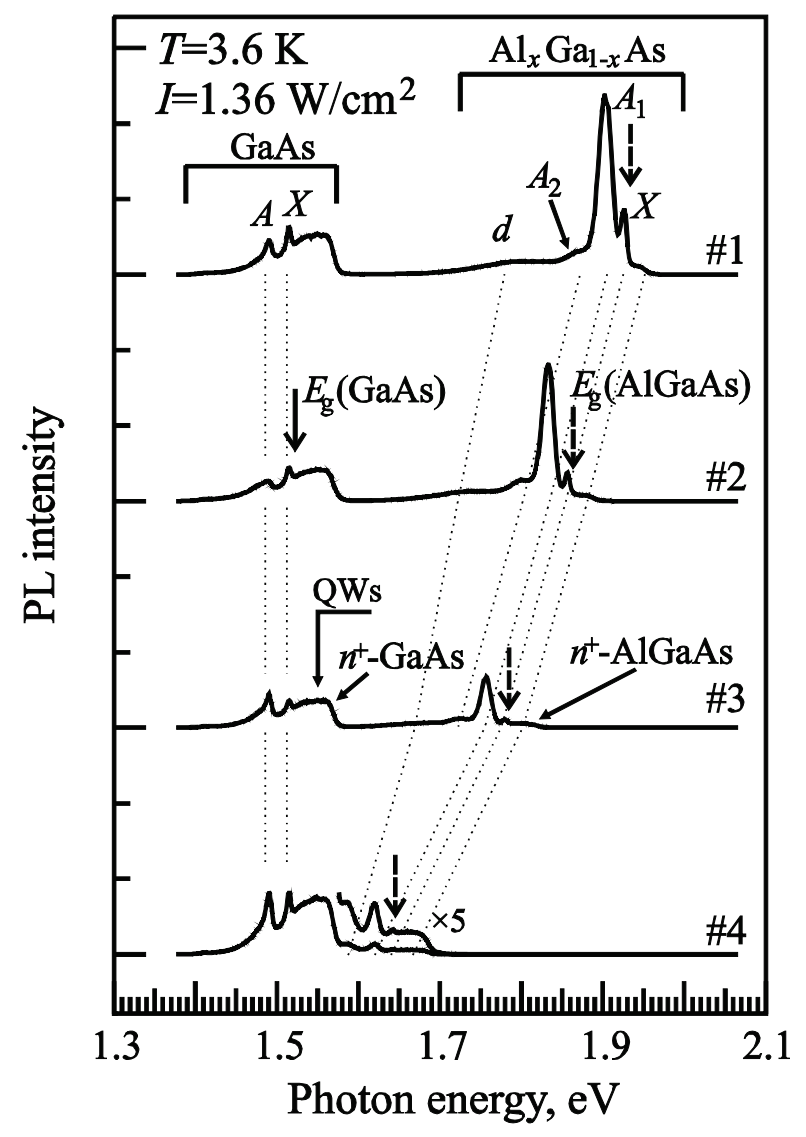

Fig. 2. The PL spectra of GaAs/Al $\mathrm{Ga}_{1-x}$ As structures at a temperature of $3.6 \mathrm{~K}$ and a laser intensity of $I=1.36 \mathrm{~W} /$ $\mathrm{cm}^{2}$ for samples with different Al mole fraction $x(0.3$ in $\# 1,0.25$ in $\# 2,0.2$ in $\# 3,0.1$ in $\# 4$ ). The spectra are shifted along the vertical axis for clarity. The scale for all the spectra is the same. The dotted lines act as guidelines for the eyes. 
two separate spectra arising from both the $n^{+}$-type and the $n$-type $\mathrm{Al}_{x} \mathrm{Ga}_{1-x}$ As layers. As Fig. 2 shows, this part of the spectrum consists of five broad peaks for the samples \#1,\#2,\#3. Only four peaks are observed in the spectrum of the $\mathrm{Al}_{x} \mathrm{Ga}_{1-x}$ As sample \#4.

In order to interpret the nature of the PL spectra lines from the $\mathrm{Al}_{x} \mathrm{Ga}_{1-x}$ As layers, the PL spectra was first measured after removing the two upper $\left(n^{+}-\right.$ GaAs and $n^{+}-\mathrm{Al}_{x} \mathrm{Ga}_{1-x}$ As) layers by chemical etching. Comparing the spectra obtained from samples with and without the (second) $n^{+}-\mathrm{Al}_{x} \mathrm{Ga}_{1-x}$ As layer demonstrates that both of the corner broad peaks ( $d$ and $n^{+}$-AlGaAs in Fig. 2) are related to the radiation from $n^{+}-\mathrm{Al}_{x} \mathrm{Ga}_{1-x}$ As. Secondly, we have performed the PL investigations of the as grown samples in a temperature range of 3.6-300 $\mathrm{K}$ using various excitation intensities. The results obtained for sample \#1 at different temperatures are shown in Fig. 3, and similar results were obtained for the other samples. The PL

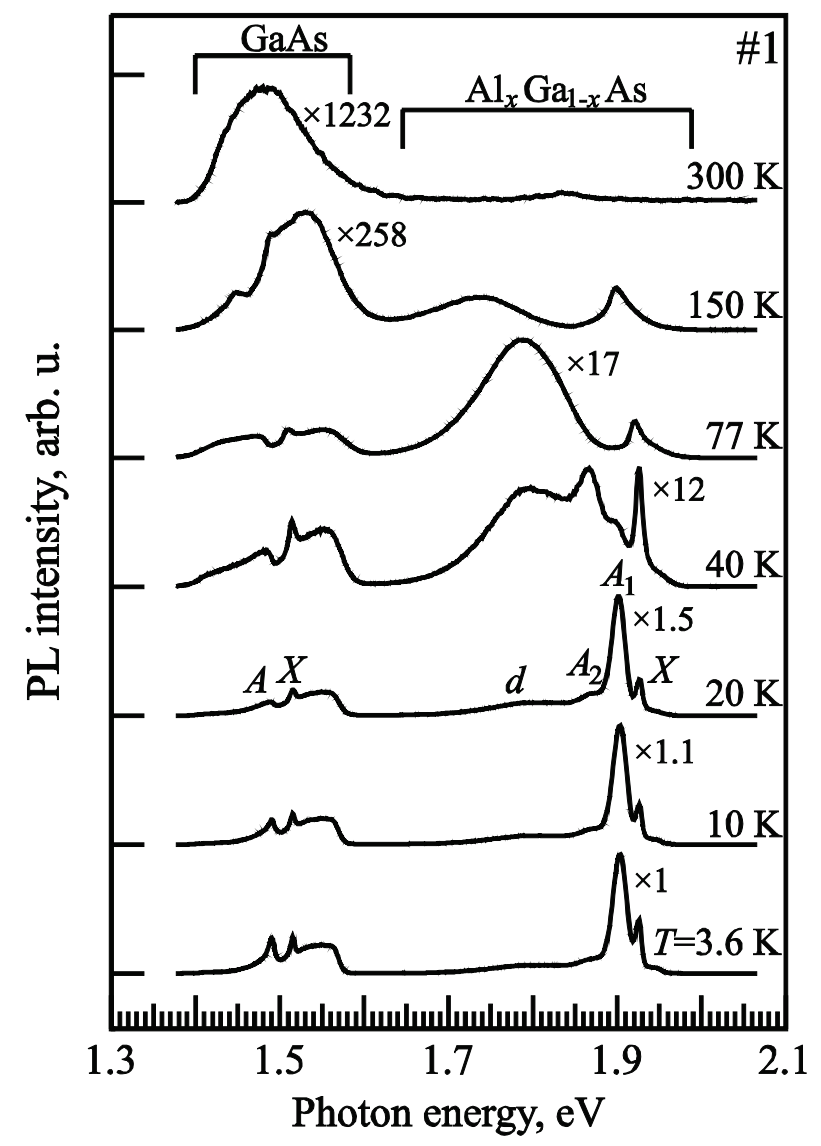

Fig. 3. The normalized PL spectra of a GaAs/ $\mathrm{Al}_{0.3} \mathrm{Ga}_{0.7} \mathrm{As}$ structure (sample \#1) at different temperatures from 3.6 to $300 \mathrm{~K}$ at a laser excitation intensity of $I=1.36 \mathrm{~W} / \mathrm{cm}^{2}$. The spectra are shifted along the vertical axis for clarity. intensity of the peak around $1.926 \mathrm{eV}$ at $3.6 \mathrm{~K}$ increases with temperature. It is a specific feature of the excitonic line. Two other peaks, labelled $A_{1}$ and $A_{2}$, of around 1.903 and $1.870 \mathrm{eV}$ at $3.6 \mathrm{~K}$ saturate and disappear above temperatures of $40 \mathrm{~K}$ and $60 \mathrm{~K}$, respectively. Consequently, they should be related to two different shallow impurities. The nature of the lowest energy broad peak, which dominates at the temperature of liquid nitrogen $(77 \mathrm{~K})$, can also be related to defects and will be discussed below.

\section{Discussion}

The energetic positions of possible emission lines have been theoretically calculated and compared with experimental results. Due to an amphoteric character of Si impurity, the Si-acceptor on the As site can also be expected in the $n$-type Si-doped $\mathrm{Al}_{x} \mathrm{Ga}_{1-x}$ As. An unintentional impurity that is commonly observed in $\mathrm{GaAs}$ and $\mathrm{Al}_{x} \mathrm{Ga}_{1-x}$ As alloys grown by MBE is carbon (C). Up until now it has been found only as an acceptor in $\mathrm{Al}_{x} \mathrm{Ga}_{1-x} \mathrm{As}$ [6]. Consequently, we used the dependence of impurity binding energy in $\mathrm{Al}_{x} \mathrm{Ga}_{1-x}$ As in the composition range of $0<x<0.4$ as: $E_{\mathrm{Si}}(D)=6.0+8.8 x$ $+7.2 x^{2}(\mathrm{meV})[6], E_{\mathrm{Si}}(A)=34.8+47.3 x+465 x^{3.5}$ $\mathrm{meV})$ [7], $E_{\mathrm{C}}(A)=26.7+5.56 x+110 x^{3.4}(\mathrm{meV})$ [8]. The $\mathrm{Al}_{x} \mathrm{Ga}_{1-x}$ As band-gap energies were calculated as $E_{\mathrm{g}}^{\mathrm{\Gamma}}(T=0 \mathrm{~K})=1.5194+1.36 x+0.22 x^{2}(\mathrm{eV}$ ) [9], and the Varshni's equation coefficients were taken from Ref. [10]. The calculated $E_{\mathrm{g}}$ values at $3.6 \mathrm{~K}$ for different samples are shown in Fig. 2 as vertical arrows.

The excitonic lines were included in all of these calculations too. The free exciton binding energy was evaluated by a quadratic interpolation $E_{x}(\Gamma)=$ $4.1+5.5 x+4.4 x^{2}(\mathrm{meV})$ [6]. The impurity bound exciton binding energies were described using Haynes' rule [11], and the above-mentioned impurity binding energies were approximated to the corresponding values in GaAs [12]. These led to the following two relationships:

$$
E_{\mathrm{DX}}=1.2+1.8 x+1.4 x^{2}(\mathrm{meV})
$$

for donor bound exciton $\mathrm{D} X$, and

$$
E_{\mathrm{CX}}=2.9+0.62 x+12 x^{3.4}(\mathrm{meV})
$$

for carbon acceptor bound exciton CX, respectively. 
A comparison of both the experimental and calculated results helped us to identify these lines. The $A_{1}$ and $A_{2}$ lines are related to the carbon and silicon-acceptor, respectively. The main part of the broad line is related to the free electron-neutral acceptor transitions. The donor-acceptor recombination is profound only at low temperatures and low excitation intensities due to donor ionisation. The highest energy edges are above the band gap energies and are related to the Fermi level in the $n^{+}$$\mathrm{Al}_{x} \mathrm{Ga}_{1-x}$ As layers.

The band $X$ in $\mathrm{Al}_{x} \mathrm{Ga}_{1-x}$ As is attributed to free and donor-bound exciton transitions at a temperature of $3.6 \mathrm{~K}$. As the temperature increases to $T>10 \mathrm{~K}$, the donor-bound exciton recombination disappears due to ionisation of the donors, and the free excitonic emission and (in part) band-to-band transitions begin to dominate.

The broad band $d$ which is visible as the lowest energy line in the $\mathrm{Al}_{x} \mathrm{Ga}_{1-x}$ As spectra shown in Figs. 2 and 3 has lower values than the minimum energy of transitions related to shallow impurity. This broad band emission is, therefore, attributed to point defects or complexes of Si with point defects. The determined dissociation energy depends on the $\mathrm{Al}$ mole fraction and varies from 60 to $140 \mathrm{meV}$. This result is in good agreement with the point defect and complex energies that are presented in [6]. A large width of this emission peak also suggests that a complex is involved in the transition.

Comparing the emission from $n-\mathrm{GaAs}$ and $n-\mathrm{Al}_{x} \mathrm{Ga}_{1-x}$ As layers with the emission from layers that are in contact with heavily doped layers revealed that emission lines from homojunctions were more intensive. This is related to the enhancement of the PL intensity found in a homojunction $[13,14]$. Hence, the results suggest that the contact of $n$-GaAs with $n^{+}$- GaAs and $n$ - $\mathrm{Al}_{x} \mathrm{Ga}_{1-x}$ As with $n^{+}-\mathrm{Al}_{x} \mathrm{Ga}_{1-x}$ As will give rise to a PL spectra intensity that is about 10 and 20 times higher, respectively.

\section{Conclusions}

The PL spectra for Si donor doped $\mathrm{GaAs} / \mathrm{Al}_{x} \mathrm{Ga}_{1-x} \mathrm{As}$ structures grown for the preparation of MW and $\mathrm{THz}$ detectors have been identified. The PL emission lines from $\mathrm{Al}_{x} \mathrm{Ga}_{1-x}$ As were a result of enhanced excitonic transitions and recombination with the
$\mathrm{C}$ - and $\mathrm{Si}$-acceptor. The broad band emission that dominates at higher temperatures is related to point defects or complexes in the material.

\section{Acknowledgements}

The MBE grown structures were grown at the Micro- and Nanotechnology Center MC2 at the Chalmers University of Technology, Sweden, under the contract No. P-01/2007 with the Lithuanian State Science and Studies Foundation. The authors acknowledge Gytis Steikūnas and Angelè Steikūnienè for the preparation of the samples.

\section{References}

[1] H. Takeuchi, J. Yanagisawa, T. Hasegawa, and M. Nakayama, Enhancement of terahertz electromagnetic wave emission from an undoped GaAs/ n-type GaAs epitaxial layer structure, Appl. Phys. Lett. 93(8), 081916-3 (2008).

[2] A. Reklaitis, Comparison of efficiencies of GaAsbased pulsed terahertz emitters, J. Appl. Phys. 101(11), 116104-3 (2007).

[3] A.G.U. Perera, H.X. Yuan, S.K. Gamage, W.Z. Shen, M.H. Francombe, H.C. Liu, M. Buchanan, and W.J. Schaff, GaAs multilayer $p^{+}-i$ homojunction far-infrared detectors, J. Appl. Phys. 81(7), 33163319 (1997).

[4] A. Sužiedèlis, S. Ašmontas, J. Kundrotas, J. Gradauskas, E. Širmulis, A. Čerškus, and V. Nargeliené, Planar heterojunction diodes for microwave and infrared applications, in: Advanced Optical Materials and Devices (AOMD-7): 7th International Conference: Vilnius, Lithuania, 28-31 August 2011: Program and abstracts (Vilnius, 2011) pp. 74.

[5] S.B. Nam, D.C. Reynolds, C.W. Litton, R.J. Almassy, T.C. Collins, and C.M. Wolfe, Free-exciton energy spectrum in GaAs, Phys. Rev. B 13(2), 761-767 (1976).

[6] L. Pavesi and M. Guzzi, Photoluminescence of $\mathrm{Al}_{x} \mathrm{Ga}_{1-x}$ As alloys, J. Appl. Phys. 75(10), 4779-4842 (1994).

[7] G. Oelgart, G. Lippold, M. Proctor, D. Martin, and F.K. Reinhart, Ionization energy of the Si acceptor in $\mathrm{Al}_{x} \mathrm{Ga}_{1-x} \mathrm{As}$, Semicond. Sci. Technol. 6(12), 1120$1125^{2}(1991)$.

[8] R. Heilman and G. Oelgart, Ionization energy of the carbon acceptor in $\mathrm{Al} \mathrm{Ga}$ As, Semicond. Sci. Technol. 5(10), 1040-1045 (1990).

[9] C. Bosio, J.L. Staehli, M. Guzzi, G. Burri, and R.A. Logan, Direct-energy-gap dependence on $\mathrm{Al}$ concentration in $\mathrm{Al}_{x} \mathrm{Ga}_{1-x}$ As, Phys. Rev. B 38(5), 3263-3268 (1988) 
[10]S. Logothetidis, M. Cardona, and M. Garriga, Temperature dependence of the dielectric function and the interband critical-point parameters of $\mathrm{Al}_{x} \mathrm{Ga}_{1-x}$ As, Phys. Rev. B 43(14), 11950-11965 (1991).

[11]J.R. Haynes, Experimental proof of the existence of a new electronic complex in silicon, Phys. Rev. Lett. 4(7), 361-363 (1960).

[12] W. Bludau and E. Wagner, Impact ionization of excitons in GaAs, Phys. Rev. B 13(12), 5410-5414 (1976).
[13]V. Kazlauskaitè, A. Sužiedèlis, A. Čerškus, J. Gradauskas, S. Ašmontas, and J. Kundrotas, Enhancement of excitonic photoluminescence in silicon-doped $n^{+} / i$ GaAs structures, Lith. J. Phys. 49(3), 285-290 (2009).

[14]J. Kundrotas, A. Čerškus, V. Nargelienè, A. Sužiedèlis, S. Ašmontas, J. Gradauskas, A. Johannessen, E. Johannessen, and V. Umansky, Enhanced exciton photoluminescence in the selectively Si-doped $\mathrm{GaAs} / \mathrm{Al}_{x} \mathrm{Ga}_{1-x}$ As heterostructures, J. Appl. Phys. 108(6), 063522-7 (2010).

\title{
MIKROBANGŲ IR TERAHERCŲ DETEKTORIAMS SKIRTU巳 GaAs/AIGaAs DARINIŲ FOTOLIUMINESCENCIJOS APIBŪDINIMAS
}

\author{
A. Čerškus a,b ${ }^{\text {, J. Kundrotas }}{ }^{\mathrm{a}}$, V. Nargeliene a ${ }^{\mathrm{a}}$, A. Sužiedèlis ${ }^{\mathrm{a}}$, S. Ašmontas ${ }^{\mathrm{a}}$, J. Gradauskas ${ }^{\mathrm{a}}$, \\ A. Johannessen ${ }^{c}$, E. Johannessen ${ }^{c}$ \\ ${ }^{a}$ Fiziniu ir technologijos mokslu centro Puslaidininkiu fizikos institutas, Vilnius, Lietuva \\ ${ }^{\mathrm{b}}$ Vilniaus pedagoginis universitetas, Vilnius, Lietuva \\ ${ }^{c}$ Vestfoldo universitetinis koledžas, Borre, Norvegija
}

\section{Santrauka}

Ištirti Si donorais legiruotų $\mathrm{GaAs} / \mathrm{Al}_{x} \mathrm{Ga}_{1-x}$ As darinių, skirtų mikrobangų ir terahercu detektoriams, fotoliuminescencijos (FL) spektrai plačiame temperatūrų intervale nuo 3,6 K iki kambario temperatūros ir esant ịvairiems žadinančios šviesos intensyvumams nuo 0,002 iki $6,8 \mathrm{~W} / \mathrm{cm}^{2} . \mathrm{Al}_{x} \mathrm{Ga}_{1-x}$ As spektre nustatytos linijos, susijusios su eksitonine spinduliuote bei rekombinacija per $\mathrm{C}$ ir Si akceptorines priemaišas. Taip pat FL spektre ma- tyti plati juosta, kurios ryšio energija priklauso nuo junginio sudèties $x$ ir kinta nuo 60 iki $140 \mathrm{meV}$. Ji susieta su taškinių defektų arba kompleksų tarp $\mathrm{Si}$ ir taškinių defektų susidarymu. Pateiktos $\mathrm{Al}_{x} \mathrm{Ga}_{1-x}$ As surištojo eksitono su akceptorine ar donorine priemaiša ryšio energijos priklausomybès nuo sudèties $x(0<x<0,4)$. Nustatytas $\mathrm{GaAs}$ ir $\mathrm{Al}_{x} \mathrm{Ga}_{1-x}$ As spektrinių linijų sustiprèjimas iki 20 kartų. Šis sustiprèjimas siejamas su $n / n^{+}$sandūrų egzistavimu šiuose dariniuose. 